\title{
Spontaneous healing response of oblique root fracture: case report with 4-year
}

\section{follow-up}

Cicatrização espontânea de fratura radicular oblíqua: relato de caso com acompanhamento de 4 anos Reparación espontánea de fractura radicular oblicua: reporte de un caso con seguimiento por 4 años

\begin{abstract}
Root fractures can involve the dentin, cementum, and pulp and commonly can occur as oblique fractures with varying orientations. The aim of this study was to demonstrate the maintenance of pulp health in a tooth with a fractured root without any endodontic treatment and to discuss the advantage of cone-bean computed tomography (CBCT) compared with traditional radiographs in the diagnosis of oblique root fractures. Intra-oral radiography of tooth 11 revealed a horizontal root fracture at the level of the apical third, while the sagittal CBCT slice reveals a complete fracture line running obliquely from the apical third on the buccal aspect through the cervical third on the palatal aspect. Four years follow-up, the tooth has kept its pulp vitality, no tooth discoloration or discrepancy in arch position, without endodontic treatment. This result illustrates spontaneous healing of root fracture including preservation of pulp health. In addition, it confirms the importance of exams in 3 dimensions to correctly locate the fracture and assist in the treatment decision.
\end{abstract}

Keywords: Dental trauma; Oblique root fracture; Spontaneous healing; Cone-beam computed tomography.

\section{Resumo}

As fraturas radiculares podem envolver a dentina, o cemento e a polpa e comumente podem ocorrer como fraturas oblíquas com orientações variadas. O objetivo deste estudo foi demonstrar a manutenção da saúde pulpar em um dente com raiz fraturada sem qualquer tratamento endodôntico e discutir a vantagem da tomografia computadorizada de feijão cônico (TCFC) em comparação com as radiografias tradicionais no diagnóstico de fraturas radiculares oblíquas. A radiografia intraoral do dente 11 revelou uma fratura radicular horizontal no nível do terço apical, enquanto a fatia sagital da TCFC revela uma linha de fratura completa que se estende obliquamente do terço apical na face vestibular até o terço cervical na face palatina. Após quatro anos de seguimento, o dente manteve a vitalidade pulpar, sem descoloração dentária ou discrepância na posição do arco, sem tratamento endodôntico. Este resultado ilustra a cura espontânea da fratura radicular, incluindo a preservação da saúde da polpa. Além disso, confirma a importância dos exames em 3 dimensões para localizar corretamente a fratura e auxiliar na decisão de tratamento. Palavras-chave: Trauma dental; Fratura radicular oblíqua; Tomografia computadorizada de feixe cônico.

\section{Resumen}

Las fracturas radiculares pueden afectar la dentina, el cemento y la pulpa y, por lo general, pueden presentarse como fracturas oblicuas con distintas orientaciones. Se reporta un caso clínico de una fractura radicular que se reparó espontáneamente sin tratamiento dental alguno y discutir la ventaja de la tomografía computadorizada de haz cónico 
(CBCT) en comparación con las radiografías tradicionales en el diagnóstico de fracturas radiculares oblicuas. Al examen radiográfico del diente 11 se observa una fractura horizontal a nivel del tercio apical, mientras que el corte sagital de CBCT revela una línea de fractura completa que corre oblicuamente desde el tercio apical en la cara bucal hasta el tercio cervical en la cara palatina. Este resultado ilustra la cicatrización espontánea de la fractura de la raíz, incluida la preservación de la salud de la pulpa. Además, confirma la importancia de los exámenes en 3 dimensiones para localizar correctamente la fractura y ayudar en la decisión del tratamiento.

Palabras clave: Trauma dental; Fractura de raíz oblicua; Reparación espontánea; Tomografía computarizada de haz cónico.

\section{Introduction}

Transverse root fractures can occur as oblique fractures with varied orientations and initial diagnosis must be based on clinical findings and radiographic examination (Abbott et al, 2019). Clinical examination includes pulp testing, evaluation of the degree of mobility, tooth position in the arch and presence of pain on palpation of the soft tissues (Polat-Ozsoy et al. 2008). In clinical practice, intraoral radiography has been the technique most commonly used to detect root fractures. However, oblique root fractures can be overlooked because of the beam angulation. CBCT imaging offers the advantage over intraoral radiography that the location, extent, and direction of a root fracture can be visualized in all three dimensions (Bornstein et al. 2009, May et al. 2013, Makowiecki et al. 2014).

Detection efficiency of the correct location and the type of root fracture are essential aspects in determining appropriate treatments. Immediate treatment with repositioning of the coronal fragment and optimal splinting seem to favor healing (Abbott et al, 2019). The splinting method with a certain flexibility of the splint are appropriate for teeth with luxation injuries and root fractures (Andreasen et al. 2004).

Pulp sensibility testing still represents the most widely used diagnostic procedure for the assessment of pulp status immediately after an acute dental trauma and should be performed initially and at each follow-up appointment in order to determine if changes occur over time, due to the temporary loss of pulpal sensibility after trauma (Cvek et al. 2002, Bastos et al. 2014, Alghaithy \& Qualtrough, 2017). Pulp necrosis and infection of the pulp space in the coronal fragment may occurs, leading to granulation tissue in the fracture line while the pulp in the apical fragment of the root remains normal because the blood supply at the apical foramen has not been affected (Ferrari et al. 2006). In this cases, endodontic treatment is limited to the coronal portion only.

Healing of an oblique root fracture may occur by calcified tissue, interposition of fibrous connective tissue and the interposition of bone and periodontal ligament around both fractured segments. Granulation tissue may form in the fracture line as a result of pulp necrosis and infection (Andreasen \& Andreasen, 2018).

This case report describes the treatment of oblique root fracture of maxillary central incisor that presented pulp vitality in both coronal and apical segments after 4-years of follow-up, without endodontic therapy recommendation. The location of the fracture and its longitudinal length was detected by CBCT images

\section{Methodology}

The case report presented composes an article with demonstrative and descriptive, exploratory purposes, exposing a qualitative approach, made through the direct technique of Pereira et al (2018), in which the researcher is an essential instrument.

\section{Case Report}

As a result of a traffic accident, a 19-year-old male presented with root fractures of the right maxillary central incisor 
with complete root formation. The patient sought dental care 2 days after trauma. No periodontal injury, signs of soft tissue damage or subjective symptoms were observed. There was no sensitivity to palpation, but the traumatized tooth was sensitive to percussion. The radiographic examination of the upper anterior region revealed a horizontal root fracture at the level of the apical third in the upper right central incisor. (Figure 1A). However, the sagittal CBCT slice of tooth 11 reveals a complete fracture line running obliquely from the apical third on the buccal aspect through the cervical third on the palatal aspect (Figure 1B). The upper left central and lateral incisors responded normally to the pulp testing with cold spray (Endo Frost, Roeko, Germany). The upper right central incisor did not respond.

Figure 1. (A) Radiographic image showing a horizontal root fracture at the level of the apical third in the upper right central incisor. (B) The sagittal CBCT slice of tooth 11 showing a complete fracture line running obliquely from the middle third on the buccal aspect through the cervical third on the palatal aspect. (C) The reduction of the root fragments and splinting with an orthodontic wire and photopolymerizable composite resin extended from canine to canine.

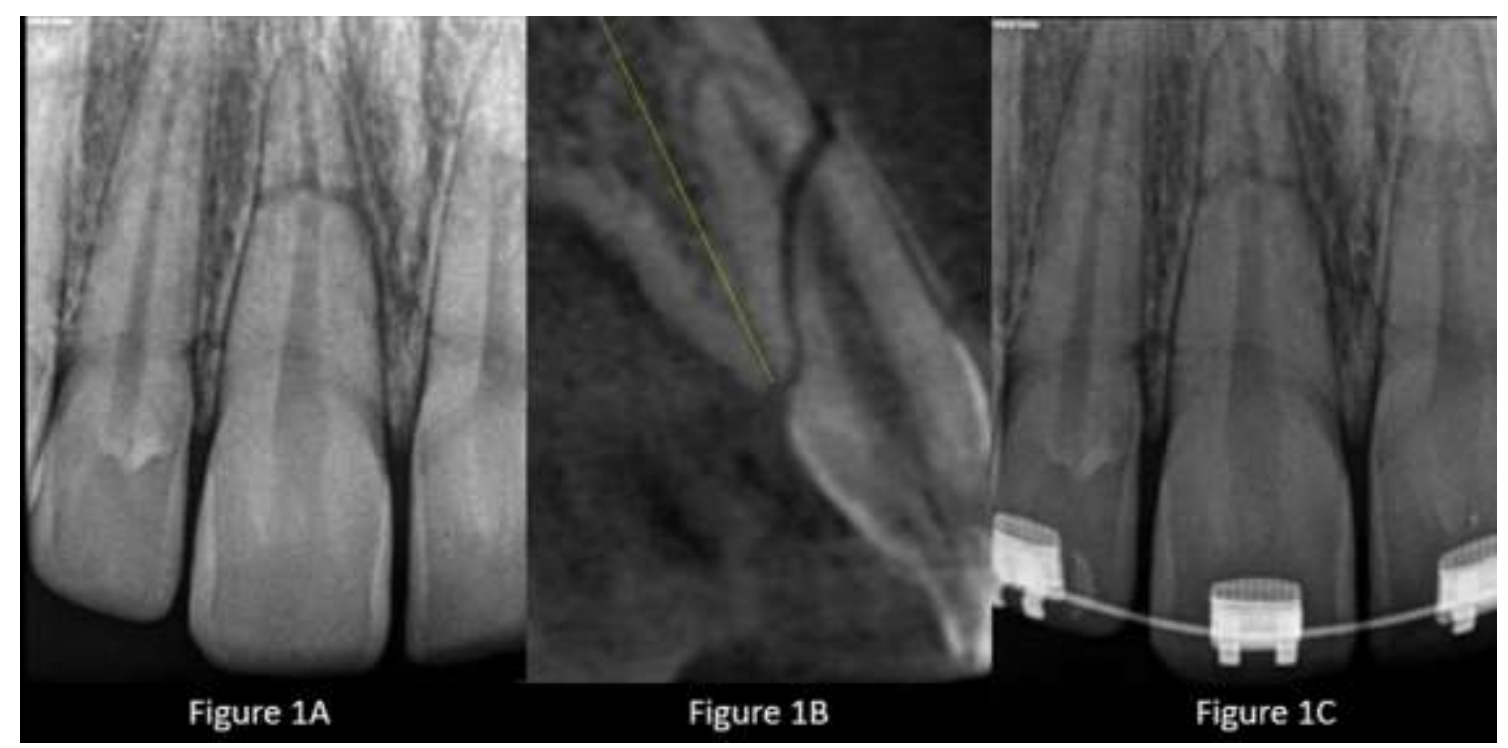

Source: Authors.

The immediate treatment consisted of the reduction of the root fragments and splinting with an orthodontic wire and photopolymerizable composite resin extended from canine to canine, which remained for 2 months (Figure 1C). After 60 days the splint was removed and the tooth responded positively to the pulp test and presented physiological mobility.

After 4 months, the tooth is still positive to sensitive tests. From then on, semiannual controls were performed for up to 2 years. Thereafter, assessments became annual to assess fracture healing and maintenance of pulp vitality.

After 16 months, obliteration of the pulp space was observed in the radiographic images, although the tooth is still positive to pulp testing (Figure 2). 
Figure 2. Radiographic appearance after a (A) 16-month and (B) 29-month follow-up. Note the pulp canal calcification and the absence of peri-apical or peri-radicular pathology.

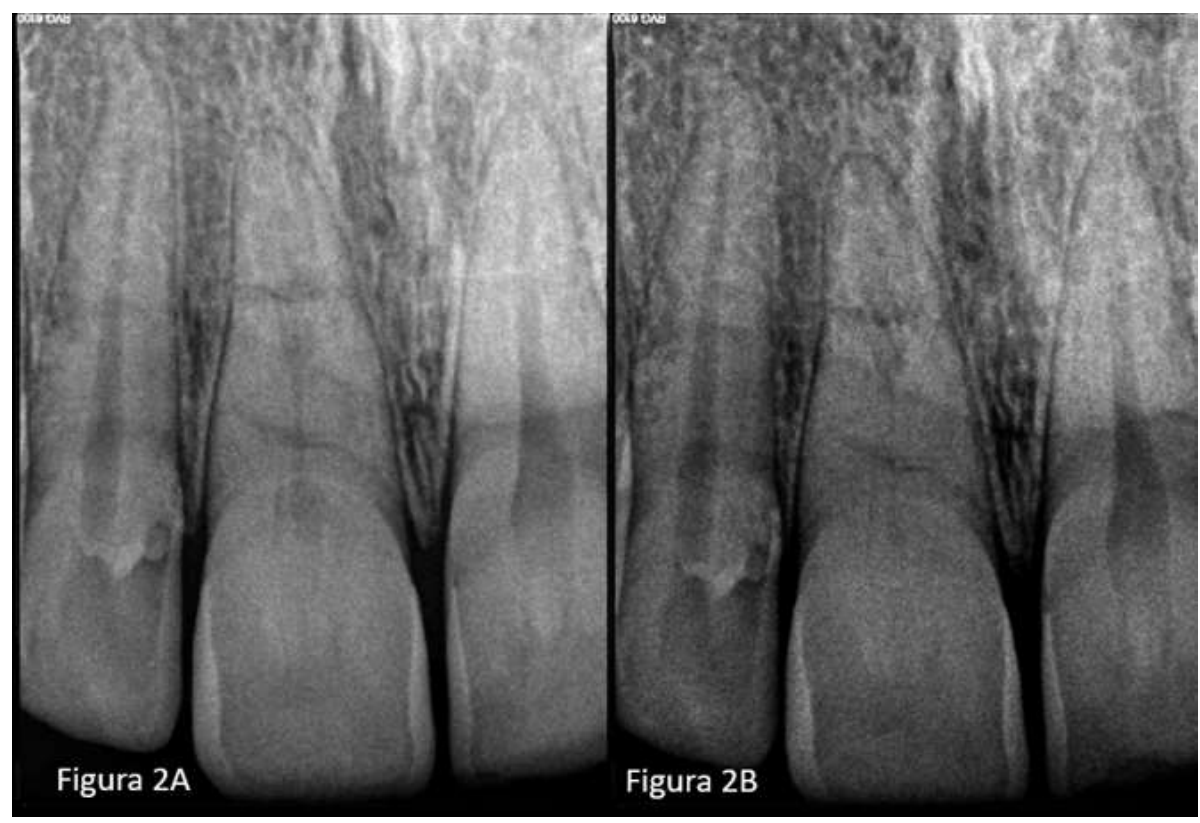

Source: Authors.

Three years later, a clinical and radiographic examination was performed and no signs or symptoms were observed. A new tomographic examination was requested and mineralized tissue interposition was observed in the fracture region, without any resorptive alterations, periradicular lesion or ligament thickening (Figure 3).

Figure 3. (A) Periapical radiograph taken 36 months later. (B) The sagittal CBCT slice of tooth 11 showing mineralized tissue interposition in the fracture region, without any resorptive alterations, periradicular lesion or ligament thickening. Note the pulp canal calcification.

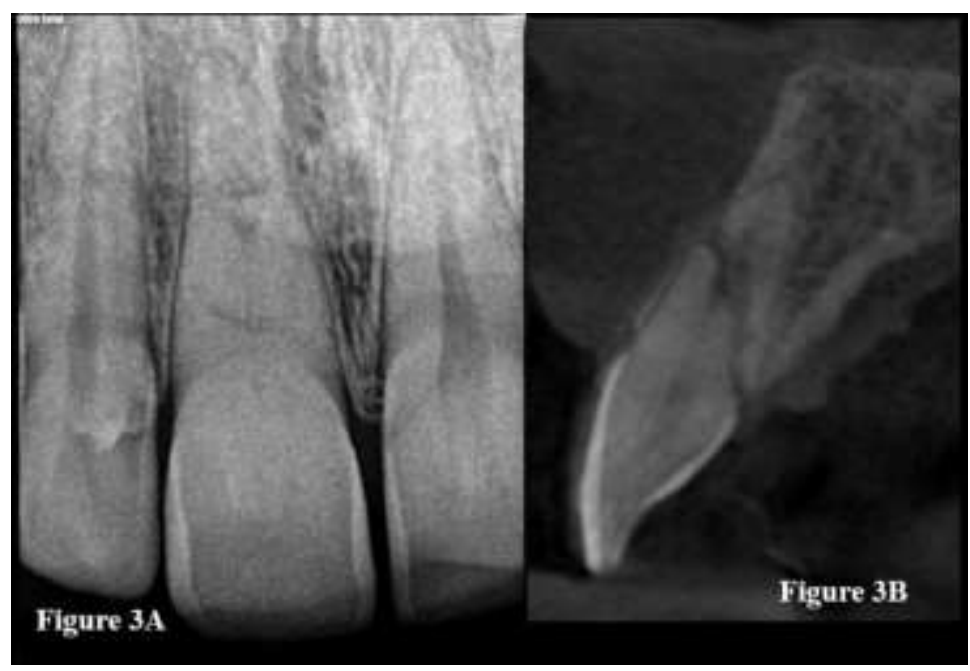

Source: Authors.

Four years later, the tooth is well positioned in the maxillary arch and has kept its pulp vitality, despite pulp space obliteration, no tooth discoloration or discrepancy in arch position. (Figure 4). 
Figure 4. (A) Periapical radiograph taken four year later showing pulp canal calcification and the absence of peri-apical or peri-radicular pathology despite pulp space obliteration. (B) Buccal and (C) palatal view photographic showing no tooth discoloration or discrepancy in arch position.

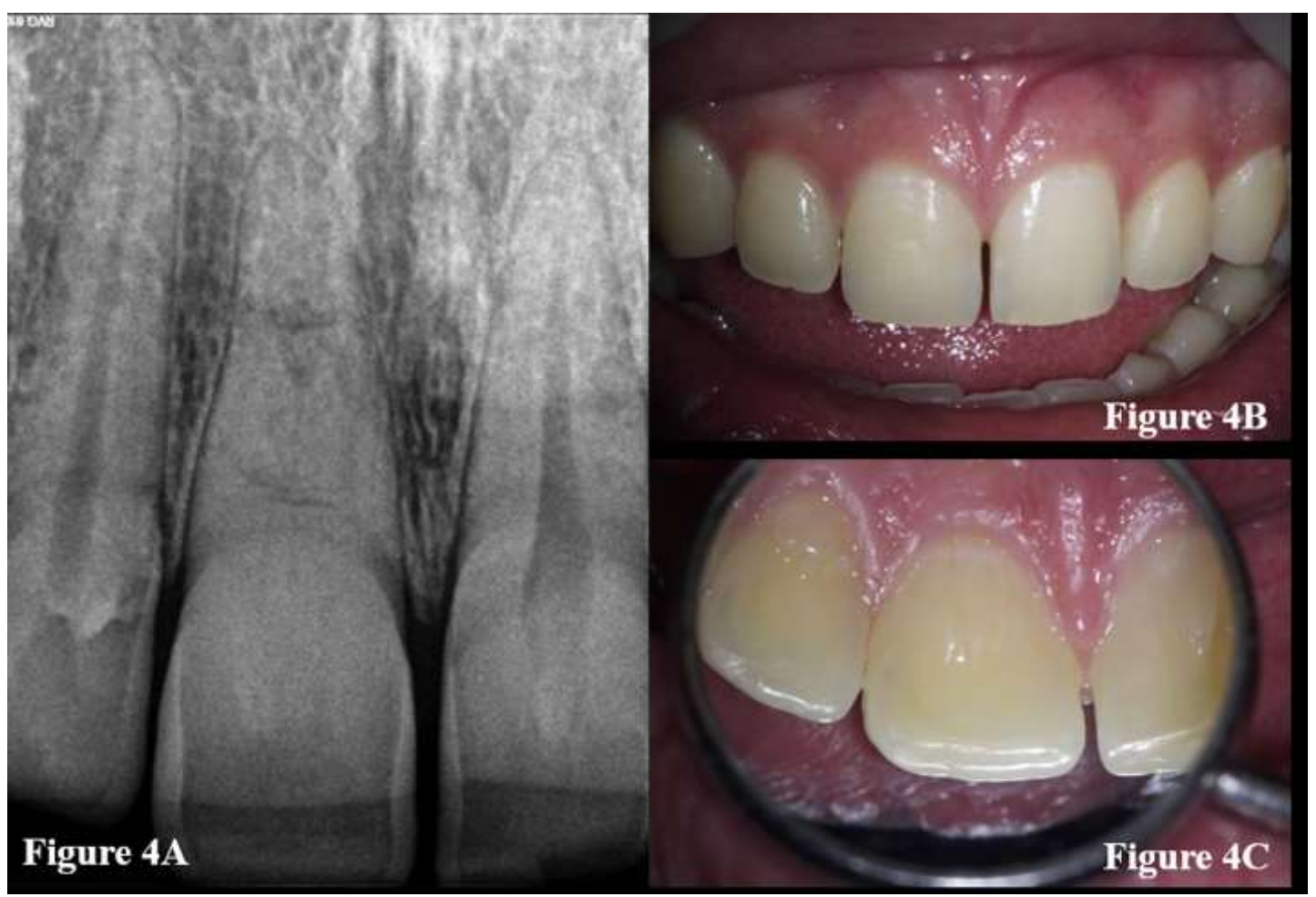

Source: Authors.

\section{Discussion}

In the present study, the sagittal CBCT slice of tooth 11 reveals a complete fracture line running obliquely from the middle third on the facial aspect through the cervical third on the palatal aspect, rather than the horizontal fracture that was diagnosed on periapical radiographs. The location of horizontal root fractures seen on conventional radiographs and CBCT may be different and the application of CBCT can aid in the accurate diagnosis of root fracture (May et al. 2013, Wang et al, 2011, Rothom \& Chuveera, 2017). Although, higher image resolution in digital intraoral radiography seem to enhance the accuracy of horizontal root fractures diagnostic imaging, root fractures might not be visible radiographically if the X-ray beam doesn't pass directly through the fracture line (Bornstein et al. 2009, Likubo et al. 2009, Nejaim et al. 2016,).

In this case the root fracture was diagnosed at the time of injury (after two days) and was splinted with orthodontic appliance for two months. However, root fracture may heal spontaneously without any treatment. It appears that there is no significant relation between the treatment delay and type of healing (Andreasen et al. 2004, Chala et al. 2009). Rapid healing of a periodontal ligament wound doesn't require a longer splinting period. However, stabilization for 2 months was needed because a part the fracture was located cervically.

The International Association of Dental Traumatology (IADT) guidelines recommend endodontic treatment only after pulp necrosis (Bourguignon et al. 2020). An initial negative response to the sensitivity tests does not indicate the further development of pulp necrosis, because the tooth may remain vital even though it does not respond to sensibility tests 18 . In the present study, the absence of a response to pulp sensibility tests in the initial visit confirm that transition from a negative to a positive response to sensibility tests, and it can be explained by the transient damage to pulpal nerve fibers. For this reason, the 
immediate pulp test should not be used to indicate root canal treatment at this early stage (Abbott et al, 2019, Bastos et al. 2014).

Healing with dental hard tissue, in this case, may have occurred because there was only a minimal displacement of the coronal fragment with immediate repositioning. Therefore, the pulp tissue was not damaged or suffered minimal displacement, becoming slightly elongated, but maintaining its blood supply. If the blood supply to the coronal fragment was cut off at some point, revascularization may have occurred, since once the coronal fragment was repositioned (Abbott et al, 2019).

Pulp space obliteration is a common root fractures post healing complication and usually indicates the presence of viable tissue within the root canal (Jacobsen \& Kerekes 1980, Heithersay \& Kahler, 2013). Apposition of hard tissue on the dentinal walls was observed, leaving only a tiny pulpal lumen. However, pulp necrosis and periradicular inflammation has so far not been observed. Pulp space obliteration had no adverse effect on the survival of the tooth and this is in accordance with previous reports (Cvek et al. 2008).

\section{Conclusion}

The present study reports a clinical case worthy of discussion around of differential diagnosis, decision making and management based on clinical guidelines. The follow-up with CBCT and pulp testing showed it to have been the best choice to follow the healing process avoiding unnecessary radical endodontic treatment. Four years later, the tooth has kept its pulp vitality despite the obliteration of the root conduct.

\section{References}

Abbott P. V. (2019). Diagnosis and management of transverse root fractures. Dental traumatology: official publication of International Association for Dental Traumatology, 35(6), 333-347.

Alghaithy, R. A., \& Qualtrough, A. J. (2017). Pulp sensibility and vitality tests for diagnosing pulpal health in permanent teeth: a critical review. International endodontic journal, 50(2), 135-142. 10.

Andreasen, F. M., Andreasen, J. O., \& Tsilingaridis, G. (2018). Root fractures. In: Andreasen, J. O., Andreasen, F. M., Andersson, L., editors. Textbook and Color Atlas of Traumatic Injuries to the Teeth. (5th ed.), Wiley Blackwell; p. 377-412.

Andreasen, J. O., Andreasen, F. M., Mejàre, I., \& Cvek, M. (2004). Healing of 400 intra-alveolar root fractures. 2. Effect of treatment factors such as treatment delay, repositioning, splinting type and period and antibiotics. Dental traumatology: official publication of International Association for Dental Traumatology, 20(4), 203-211.

Bastos, J. V., Goulart, E. M., \& de Souza Côrtes, M. I. (2014). Pulpal response to sensibility tests after traumatic dental injuries in permanent teeth. Dental traumatology: official publication of International Association for Dental Traumatology, 30(3), $188-192$.

Bornstein, M. M., Wölner-Hanssen, A. B., Sendi, P., \& von Arx, T. (2009). Comparison of intraoral radiography and limited cone beam computed tomography for the assessment of root-fractured permanent teeth. Dental traumatology: official publication of International Association for Dental Traumatology, 25(6), $571-577$.

Bourguignon, C., Cohenca, N., Lauridsen, E., Flores, M. T., O'Connell, A. C., Day, P. F., Tsilingaridis, G., Abbott, P. V., Fouad, A. F., Hicks, L., Andreasen, J. O., Cehreli, Z. C., Harlamb, S., Kahler, B., Oginni, A., Semper, M., \& Levin, L. (2020). International Association of Dental Traumatology guidelines for the management of traumatic dental injuries: 1. Fractures and luxations. Dental traumatology: official publication of International Association for Dental Traumatology, 36(4), 314-330.

Chala, S., Sakout, M., \& Abdallaoui, F. (2009). Repair of untreated horizontal root fractures: two case reports. Dental traumatology: official publication of International Association for Dental Traumatology, 25(4), 457-459.

Cvek, M., Mejàre, I., \& Andreasen, J. O. (2002). Healing and prognosis of teeth with intra-alveolar fractures involving the cervical part of the root. Dental traumatology: official publication of International Association for Dental Traumatology, 18(2), 57-65.

Cvek, M., Tsilingaridis, G. \& Andreasen, J.O. (2008). Survival of 534 incisors after intra-alveolar root fracture in patients aged 7-17 years. Dental traumatology: official publication of International Association for Dental Traumatology, 24(4), 379-87.

Ferrari, P. H., Zaragoza, R. A., Ferreira, L. E., \& Bombana, A. C. (2006). Horizontal root fractures: a case report. Dental traumatology: official publication of International Association for Dental Traumatology, 22(4), 215-217. 
Research, Society and Development, v. 10, n. 3, e30710313144, 2021

(CC BY 4.0) | ISSN 2525-3409 | DOI: http://dx.doi.org/10.33448/rsd-v10i3.13144

Heithersay, G. S., \& Kahler, B. (2013). Healing responses following transverse root fracture: a historical review and case reports showing healing with (a) calcified tissue and (b) dense fibrous connective tissue. Dental traumatology: official publication of International Association for Dental Traumatology, 29(4), 253-265.

Jacobsen, I., \& Kerekes, K. (1980). Diagnosis and treatment of pulp necrosis in permanent anterior teeth with root fracture. Scandinavian journal of dental research, 88(5), 370-376

Likubo M, Kabayashi K, Mishims A et al. (2009) Accuracy of intraoral radiography, multidetector helical CT, and limited cone-beam CT for the detection of horizontal tooth root fracture. Oral Surgery, Oral Medicine, Oral Pathology, Oral Radiology, Endodontics 108, 70-4.

Makowiecki, P., Witek, A., Pol, J., \& Buczkowska-Radlińska, J. (2014). The maintenance of pulp health 17 years after root fracture in a maxillary incisor illustrating the diagnostic benefits of cone bean computed tomography. International endodontic journal, 47(9), 889-895.

May, J. J., Cohenca, N., \& Peters, O. A. (2013). Contemporary management of horizontal root fractures to the permanent dentition: diagnosis--radiologic assessment to include cone-beam computed tomography. Journal of Endodontics, 39(3 Suppl), S20-S25.

Nejaim, Y., Gomes, A. F., Silva, E. J., Groppo, F. C., \& Haiter Neto, F. (2016). The influence of number of line pairs in digital intra-oral radiography on the detection accuracy of horizontal root fractures. Dental traumatology: official publication of International Association for Dental Traumatology, 32(3), 180 184.

Polat-Ozsoy, O., Gülsahi, K., \& Veziroğlu, F. (2008). Treatment of horizontal root-fractured maxillary incisors--a case report. Dental traumatology: official publication of International Association for Dental Traumatology, 24(6), e91-e95.

Rothom, R., \& Chuveera, P. (2017). Differences in Healing of a Horizontal Root Fracture as Seen on Conventional Periapical Radiography and Cone-Beam Computed Tomography. Case reports in dentistry, 2017, 2728964.

Wang, P., He, W., Sun, H., Lu, Q., \& Ni, L. (2011). Evaluation of horizontal/oblique root fractures in the palatal roots of maxillary first molars using conebeam computed tomography: a report of three cases. Dental traumatology: official publication of International Association for Dental Traumatology, 27(6), $464-467$.

Westphalen, V., Carneiro, E., Fariniuk, L. F., da Silva Neto, U. X., Westphalen, F. H., \& Kowalczuck, A. (2017). Maintenance of Pulp after Horizontal Root Fractures in Three Maxillary Incisors: A Thirteen-Year Evaluation. Iranian endodontic journal, 12(4), 508-511. 